\title{
The Cameroonization of English
}

\author{
Paul Mbufong \\ University of Douala, Douala, Cameroon
}

\begin{abstract}
This paper addresses the consequences of the spread of the English language all over the world, but particularly in non-native environments like Cameroon, where it remains a L2 (second language) and is one of two official languages (French being the other) competing with over 280 home languages. With this spread, English has had to take on local colourings as it gets in contact with home languages. Kachru (1986) referred to this process, as nativization. The aim of this paper is to apply the Kachruvian concept of nativization with regards to the use of English in Cameroon by users who are native speakers of languages other than English. A comparison of some features of CE (Cameroon English) and British English is made at the levels of phonology, lexis, and grammar. The results suggest that local languages like Lamso, Bafut, Eton, Mungaka, Mokpe, etc., have influenced English as used in Cameroon. In Kachruvian terms, English has been nativized/cameroonized. It is concluded that while nativization is the natural and inevitable result of linguistic and cultural content, Cameroon's intralingualism and cultural pluralism have added further levels of complexity to the simple idea of conscious or unconscious innovations in the language functionally to adapt it to the local milieu.
\end{abstract}

Keywords: culture, nativization, cultural pluralism

\section{Introduction}

In discussing the life cycle of New Englishes, Moag (1982) used several terms "transportation and expansion", "institutionalization", "restriction in use and function", and "indigenization".

"Transportation" refers to the process whereby English was brought to a new environment for purposes of exploration, trade, colonial administration, and religion.

"Expansion in use and function" means the extension of English, hitherto used only by the local elite, to a wider population of indigenes for education, the media, and administrative transactions.

"Institutionalization" is the adoption of the new variety for a wider range of functions within the recipient community. It is marked by the increasing divergence from the imported norm. This divergence is reinforced by indigenous creative writers, national teachers, and the media handled by local personnel.

"Indigenization" is also known in the literature as "localization", "contextualization", or "nativization" (Kachru, 1982, p. 1) - is the phenomenon whereby the new variety of English becomes distinct from the current native variety, and from other local varieties elsewhere. Indigenization is often marked by the transfer of local features into English lexicology and grammar, by the interference of the sounds of local languages with English, or the outright restructuring of the sound system of the imported language.

Paul Mbufong, doctor, Department of English and Foreign Languages, University of Douala. 
The last process, indigenization, is the subject of this paper. And the author uses the term "Cameroonization" to refer to the nativization or indigenization of English in Cameroon. In other words, Cameroonization could be defined following Richards, Platt, and Weber (1999, p. 188) as: the adaptation the English language has undergone, is undergoing in the cultural and social situation of Cameroon.

The colonial transplant of English after World War I has taken root in Cameroon and flourishes today as a Cameroonian language in its own right. It certainly made a great revolution. In southern Cameroon (the northwest and southwest regions), English became the primary medium of education and with its adaptation, there came the earliest efforts towards the "Englishization" (Kachru, 1986) of Cameroon although it is doubtful if this process created Cameroonians in blood and color, but English in taste, opinion, in morals, and in intellect. In turn, a firm foundation was however laid for the localization of the English language in Cameroon.

English in Cameroon, for example, is said to have undergone nativization, because changes have occurred in aspects of phonology, vocabulary, and grammar, so that it is now recognised as a district variety of English - CE (Cameroon English).

In its Cameroonized form, English has now become an integral part of Cameroon's linguistic repertoire. The peculiar Cameroonian situation and the experiences of Cameroonians make a local variety of English imperative. It is also clear that "pure" British English cannot function effectively in Cameroon any more than it can in the United States or South Africa. While nativization is the natural result of linguistic and cultural content, this paper argues that Cameroon's intralingualism and ethnic pluralism have added further levels of complexity to the simple idea of conscious or unconscious innovations in the language to functionally adapt it to the local milieu. In mixing (Clyne, 1972) words, phrases, clauses, and idioms from Cameroonian languages, PE (Pidgin English), and French into English, or in switching (Fishman, 1971) from one language identity into another, Cameroonians are not just using a code; they are also expressing an identity, a linguistic belonging to a geographical location called Cameroon. When a Cameroonian opens his/her month to speak English, the Cameroonian identity is transparent. This identity is not only the pronunciation of some vowels or consonants or in the stressing (or lack of stressing) of words, but is deeper than that: It is in the rhythm and the pauses. Cameroonians were never encouraged to speak like the "master". The "accent bar" (Abercrombie, 1951) was purposely used by the British as a linguistic indicator for maintaining a distance between the "masters" and the "natives".

\section{The Linguistic Situation in Cameroon}

Cameroon, a country of over 12 million inhabitants (the 1987 Census) covering a surface area of 475,000 $\mathrm{km}^{2}$ is said to have been "discovered" by Portuguese explorers in 1472 (Chumbow \& Bobda, 1996, p. 402).

The great majority of Cameroonians are either bilingual or multilingual. This bilingualism and or multilingualism should be no surprising thing, for according to the linguistic atlas of Cameroon there 239 indigenous languages belonging to many totally different families (Chumbow \& Bobda, 1996, p. 44). This makes Cameroon one of the most linguistically complex nations in the world. As a result of inter-ethnic interaction, many Cameroonians are capable of mastering a number of these languages and can thus code switch spontaneously depending on the interlocutors involved.

Superimposed on the national languages, transcending ethnic boundaries are the two official 
languages - French and English in that order. These official languages are European languages which were inherited from France and England at independence in 1961 when French dominated Cameroon, then known as East Cameroon which became federated, then British dominated Southern Cameroon. Subsequently in 1972 and 1984, the official status of French and English were upheld in the constitutions of the reunited Cameroon and the Republic of Cameroon respectively.

Officially, French and English are considered languages of equal status. Affairs of the state may be conducted in either language. Official bilingualism in French and English does not imply that one is obliged to master both languages but rather that one should speak at least one of the official languages to be able to get by in official matters. In this light, the teaching of French in Anglophone schools and English in Francophone schools is greatly encouraged.

Besides the national languages and the colonial languages, there exists in Cameroon a lingua-franca (Wardhaugh, 1992, pp. 56-58) known as CPE (Cameroon Pidgin English). CPE is used all over the nation. In fact, most Cameroonians who can speak neither French nor English do speak some CPE. Such is the vitality of CPE in Cameroon that 30 years ago, Todd (1969) had recommended its use as a national language in Cameroon given that it is widely used and ethnically neutral. Oben (1999) argued that CPE has become unofficially official in the sense that it is central to the lives of many Cameroonians especially those in the northwest and southwest regions. Many children already speak CPE before they come to school and those who do not pick it up within a few weeks of starting school. CPE is the language used by Cameroonians from diverse linguistic backgrounds. As Povey, Chia, and Koenig (1983) put it:

If one examines the overall figures..., it is not Fulfulde, and it is certainly not Standard English that has established itself as the most widespread and therefore, the most useful means of communication in Cameroon; it is Pidgin English. (p. 15).

It may be useful to add following Povey, Chia, and Koenig (1983) that it is not French either that has established itself as the most widespread and therefore, the most useful means of communication in Cameroon; it is CPE. PE is the language of intimacy and of casual and informal dealings. Even in francophone towns, Povey, Chia, and Koenig's (1983) survey showed PE to be competing very seriously with French. For example, in Nkongsamba, Bafang, Douala, Bafoussam, and Dschang, the number of adults who speak PE is higher than, equal to or only slightly lower than that of those who speak French as seen in Table 1.

Table 1

PE/French Use in Francophone Towns

\begin{tabular}{llllll}
\hline & Nkongsamba (\%) & Bafang (\%) & Douala (\%) & Bafoussam (\%) & Dschang (\%) \\
\hline PE & 95 & 91 & 90 & 72 & 78 \\
FR (French English) & 84 & 81 & 90 & 93 & 91.5 \\
\hline
\end{tabular}

Note. Source: Povey, Chia, and Koenig (1983).

Educated Cameroonians are multilingual in at least any three of the following languages: an indigenous or HL (home language), a number one L2 (second language), CPE, and a number two L2. The order of acquisition may vary, but in the majority, either the HL or the number one L2 is acquired first. For more exhaustive 
discussions on the patterns of acquisition (see the classifications of Mbassi Manga, 1976; Soh, 1976; Tiayong, 1990, as cited in Forsab, 1992, p. 17).

While the nativization of English in Cameroon is probably influenced by three factors, i.e., home languages, PE, and French, this paper will focus on the influence of HLs; and the influence of HLS on English will be discussed at the levels of phonology lexis and grammar. The reason for restricting the focus on HLS is that HLS is what is the quintessential Cameroonian; although PE and French are used in Cameroon, they are not Cameroonian languages, strict senso. Furthermore, the influence of French (Kouega, 2005) and PE (Oben, 1999) have been the subject of earlier useful research.

\section{Home Language Phonological Influences on English}

Table 2 provides some examples of home language which influence on Cameroon English phonology. For example, Lamso, a language spoken in the northwest region of the country is characterized by a monophongisation of diphthongs. Words with the diphthong /au/as in low become / $\mathrm{u} /$. This is apparently because the /ou/ diphthong does not exist in the Lamso vowel system.

Table 2

Monophongisation of English Diphthongs by Lamso Speakers

\begin{tabular}{|l|l|l|l|}
\hline Word & Standard English & Home language & Cameroon English \\
\hline Goat & /gəut/ & Lamso & $/ \mathrm{gut} /$ \\
\hline Show & $/ \mathrm{gau} /$ & Lamso & $/ \mathrm{gu} /$ \\
\hline Go & $/ \mathrm{gəu} /$ & Lamso & $/ \mathrm{gu} /$ \\
\hline
\end{tabular}

The long /i:/ vowel sound is realized as /e/ by Lamso speakers as seen in Table 3. There is thus a reduction of long vowels to short vowels. Of course, different speakers show different degrees of approximation to RP (received pronunciation).

Table 3

The Realization of /i:/ by Lamso Speakers

\begin{tabular}{|l|l|l|l|}
\hline Word & Standard English & Home Language & Cameroon English \\
\hline Meat & $/ \mathrm{mi}: \mathrm{tt} /$ & Lamso & $/ \mathrm{m} \varepsilon t /$ \\
\hline Me & $/ \mathrm{mi} / /$ & Lamso & $/ \mathrm{m} / /$ \\
\hline Mean & $/ \mathrm{mi}: \mathrm{n} /$ & Lamso & $/ \mathrm{m} \varepsilon \mathrm{n} /$ \\
\hline
\end{tabular}

In Mokpe and Mungaka, the voiced roll alveolar trill consonant $/ \mathrm{r} /$ is realized as /1/ as in Table 4.

Table 4

Mokpe and Mungaka Realization of the English / $r /$

\begin{tabular}{|l|l|}
\hline rr/ & $/ 1 /$ \\
\hline$\underline{\text { Rubber }}$ & Lubber \\
\hline$\underline{\text { Rice }}$ & Lice \\
\hline$\underline{\text { Run }}$ & Lun \\
\hline$\underline{\text { Problem }}$ & Ploblem \\
\hline$\underline{\text { Road }}$ & Load \\
\hline
\end{tabular}


In Bafut, a language spoken in the Northwest region, the voiceless bilabial plosive $/ \mathrm{p} /$ is realized as $/ \mathrm{b} /$, its voiced counterpart:

$\mathrm{Plum} / \mathrm{pl} \wedge \mathrm{m} /==>$ blum $/ \mathrm{blom} /$

Plot $/$ plot $/==>$ blot $/$ blot $/$

Pear $/$ pea/ ==> bear $/$ b $\varepsilon$ :/

In Eton, a language spoken in the centre region, the voiceless interdental fricative $/ \theta /$ as in "thin" is instead realized as the voiceless alveolar plosive /t/ tin/ while the voiced interdental fricative /_aet/ as in /_aet/ is realized as the voiced alveolar plosive/d//daet/. There is a tendency for final consonants to be reduced: last /las/ passed /pas/ and for final voiced consonants to be devoiced proud /praud/v. /praut/ robe /roub/ v. /rop/.

In Bassa, the voiced alveolar fricative / $z /$ seen in "because"/biko:z/ is realized as the voiceless alveolar fricative /s//biko:s/.

Apart from these specific influences of Cameroon home languages on standard English, general and extensive phonological differences between CE and RP for e.g., the fact that CE is syllable timed while English is stress timed have been identified (Bobda \& Mbangwana, 1993; Bobda, 1994).

\section{Home Language Lexical Influences on English}

The influence of home languages on English is mostly felt in the area of vocabulary. It is in this domain that we easily see the originality and the particularity of Cameroon English. Understandably, Cameroon English vocabulary reflects the local socio-cultural realities and attitudes of the users. There is a range of words borrowed from local languages in some cases, because these are no readily available English equivalents or because local words are more convenient as seen in Tables 5-6 as regards clothes and food items respectively.

Table 5

Dress Lexical Items From Some Cameroonian Languages

\begin{tabular}{|l|l|l|l|}
\hline Cameroonian language & Lexical item & Cameroon standard English & Meaning \\
\hline Mokpwe & Kaba & Kaba: I bought a kaba for my wife. & A big loose dress \\
\hline Mokpwe/Oroko & Sandja & Sandja: He has on a sandja. & Loin cloth for men \\
\hline Fulani & Bouba & Bouba: My mother's bouba is white. & Blouse \\
\hline Mokpe/Douala & Mboti & Mboti: I bought some mboti in Soppo market. & Clothes \\
\hline
\end{tabular}

Table 6

Food Lexical Items From Some Cameroonian Languages

\begin{tabular}{|l|l|l|l|}
\hline $\begin{array}{l}\text { Cameroonian } \\
\text { language }\end{array}$ & $\begin{array}{l}\text { Lexical } \\
\text { item }\end{array}$ & Cameroon standard English & Meaning \\
\hline Mokpwe/Oroko & Ekwang & Ekwang we had ekwang for lunch yesterday. & Grated cocoyam wrapped in green vegetables \\
\hline Bayang & Eru & Eru fufu and eru is quite popular among the Bayangs. & Wild green vegetables \\
\hline Bafut/Mankon & Achu & Achu will be on the menu on Monday. & Pounded cocoyam \\
\hline Douala & Ndole & My daughter likes ndole and plantains. & Bitter leaves mixed with groundnuts \\
\hline
\end{tabular}




\section{Home Language Grammatical Influences on English}

Table 7 provides some examples of home language influence on Cameroon English grammar.

Table 7

Use of Verbs in Cameroon English

\begin{tabular}{|l|l|l|}
\hline Standard English & Home languages & Cameroon English \\
\hline $\begin{array}{l}\text { (1) To smell } \\
\text { I can smell rice }\end{array}$ & $\begin{array}{l}\text { Mungaka: nju dzet } \\
\text { Mokpe: li weja ezrundzu } \\
\text { Oroko: di bako esundzu }\end{array}$ & I can hear the smell of rice \\
\hline $\begin{array}{l}\text { (2) To smoke } \\
\text { John is smoking a cigarette }\end{array}$ & $\begin{array}{l}\text { Mungaka: nu ndiba } \\
\text { Mokpe: Li no zrika } \\
\text { Oroko: di na esika }\end{array}$ & John is drinking cigarette \\
\hline $\begin{array}{l}\text { (3) To cook food } \\
\text { I am cooking some food }\end{array}$ & $\begin{array}{l}\text { Akose : nt same mbe } \\
\text { Lamso: im na ntsin } \\
\text { Oroko: kire mbeya }\end{array}$ & Iam cooking pot \\
\hline
\end{tabular}

Table 7 shows that for home languages as diverse in origin as Mungaka (from the Northwest, Mokpe (from the Southwest) the effect on English is the same. One can only chuckle at the curious suggestion that Cameroonians use their ears (hear) to smell rather than their noses and cook the container for food rather than food itself.

Table 8

"Wh" Questions in Cameroon English

\begin{tabular}{|c|c|c|}
\hline Standard English & Home languages & Cameroon English \\
\hline Who are you? & $\begin{array}{l}\text { Mungaka: ubowu? } \\
\text { Mokpe: owa ndze? } \\
\text { Oroko: owa ndza? }\end{array}$ & You are who? \\
\hline What has he said? & $\begin{array}{l}\text { Mungaka: ija ko? } \\
\text { Oroko: om danara nawe } \\
\text { Mokpe: à ma māme? }\end{array}$ & He has said what? \\
\hline Where are you going? & Mokpe: wend oné? & You are going to where? \\
\hline
\end{tabular}

Table 8 shows that systematically, who, what, and where which occur in initial position in English, occur in final position in Cameroon home languages. However, it has to be admitted that $\mathrm{CE}$ varies according to the education of the speaker and the formality of the occasion. In which case, some of the forms given above are not used by the most educated users, at least not in writing. Put differently, the interference of local languages is most marked in less educated and more informal styles.

Table 9

Omission of Articles in Cameroon English

\begin{tabular}{|l|l|l|}
\hline Standard English & Home languages & Cameroon English \\
\hline I am going to the cinema & $\begin{array}{l}\text { Mokpe: ne nde au cinema } \\
\text { Bassa: minke i cinema } \\
\text { Bafut: mare cinema }\end{array}$ & \\
\hline
\end{tabular}

Table 9 shows that, because the determiner "the" does not occur in Cameroonian languages like Bassa, Mokpe or Bafut, Cameroon English tends to omit "the" before the noun "cinema". So we find structures in Cameroon English like "I can play guitar" when the standard English form would be "I can play the guitar". 
Use of resumptive pronouns not only after focused nouns as in some colloquial styles of English: My father, he is kind, but also in relative clauses.

Table 10

Use of Resumptive Pronouns in Relative Clauses

\begin{tabular}{|l|l|l|}
\hline Standard English & Home languages & Cameroon English \\
\hline The guests I invited have come & $\begin{array}{l}\text { Mokpe: wa tu naria va maja } \\
\text { Bassa: Baken ba wemisebs banlò } \\
\text { Bafut: babia mebitongmə be jimə }\end{array}$ & $\begin{array}{l}\text { The guests I invited (they) have } \\
\text { come }\end{array}$ \\
\hline
\end{tabular}

Table 10 shows that in standard English, we do not need resumptive pronouns after the noun (the guests). Cameroonian languages on other hand, tend to include resumptive pronouns as a way of reiterating or reinforcing the noun (the guests) which occurs in subject initial position by the use of the third person plural pronoun "they".

The use of a universal tag question "na" regardless of person, tense, or main clause auxiliary.

Table 11

Tag Questions in Cameroon English

\begin{tabular}{|l|l|l|}
\hline Standard English & Home languages & Cameroon English \\
\hline We should leave now, shouldn`t we? & Bafut: Tabi re tsitsong noh? & ${ }^{*}$ We should leave now na? \\
\hline Mum bought the shoes, didn't she? & Bafut: mami jumə ntay njia noh? & ${ }^{*}$ Mum bought the shoes na? \\
\hline
\end{tabular}

Table 11 demonstrates that while standard English uses different tag questions, for example, "shouldn't we?", or "didn't she?", there is only one tag question ("noh?") in Cameroonian languages. And this tag question becomes "na?" in Cameroon English irrespective of the person and number of the subject of the sentence.

\section{Conclusions}

Cameroon English is just one of the many varieties which spice up the English language. It is not better/worse than any other variety; it is different. Cameroon English is no mere exotic sideshow, but an important site of contact, negotiation, and linguistic and literary creativity. The characteristics discussed in this paper were once regarded as errors but are now increasingly accepted as distinctive contributions to the English language.

While the Cameroonization of English gives Cameroonians a special identity, we have to recognize that Cameroonization is not necessarily linguistic bliss, nor is it a declaration of linguistic emancipation against other Englishes. It is a natural result of prolonged linguistic and cultural contact. Its implications, as of other institutionalised non-native varieties, are multifaceted and are just being recognized. These raise various theoretical and methodological questions and doubts, specifically about communicative competence in English in a global context, about intelligibility and about the current research paradigms of second language acquisition. We believe that as long as deviations from English-English are not too great to impair wider communication, there is not much of a problem if English has grown Cameroonian roots.

\section{References}

Abercrombie, D. (1951). RP and local accent. Listener, 6 (Reprinted in D. Abercrombie, Studies in phonetics and linguistics. London: Oxford University Press).

Abercrombie, D. (1963). Problems and principles in language study. London: Longman.

Bobda, S. (1994). Aspects of Cameroon English phonology. Benn: Peter Lang. 
Bobda, S., \& Mbangwana, P. (1993). An introduction to English speech. Lagos: University of Lagos Press.

Chumbow, S. B., \& Bobda, S. (1996). The life-cycle of post-imperial English in Cameroon. In J. Fishman (Ed.), Contributions to the sociology of language. New York: Mouton de.

Clyne, M. (1972). Perspectives on long language contact. Melbourne: The Hawthorne.

Fishman, J. A. (1971). Advances in the sociology of language 1. The Hague: Mouton.

Forsab, N. A. (1992). Official language bilingualism in the university of Yaoundé: Some educational and social issues (Unpublished postgraduate diploma dissertation, University of Yaoundé).

Kachru, B. B. (1982). The alchemy of English. Oxford: Pergamon.

Kachru, B. B. (1986). The indianization of English. English Today, 6, 31-33.

Koueaga, J. P. (2005). The effects of French on English L2 in Cameroon. In K. T. Cohen, K. McAlister, \& J. Macswan (Eds.), Proceedings of the 4th international symposium on bilingualism (pp. 1201-2010). Somerville, M.A.: Cascalia Press.

Moag, R. (1982). English as a foreign, second, native and basal language, a new taxonomy of English-speaking societies. In J. B. Pride (Ed.), New Englishes. Rowley Mass: Newbury Home Publishers, Inc..

Oben, A. B. (1999). The influence of Pidgin English on the learning of the english language in the university of Buea (Unpublished M.A. thesis, University of Buea).

Povey, J., Chia E., \& Koenig, E. L. (1983). A sociolinguistic profile of urban centres in Cameroon. Los Angeles: Crossroads Press.

Richards, J., Platt, J., \& Weber, H. (1999). Longman dictionary of applied linguistics. London: Longman.

Todd, L. (1969). English in Cameroon: Education in a multilingual society. In J. O. B. Pride (Ed.), New Englishes. Rowley, M.A.: Newbury House Publishers.

Wardhaugh, R. (1992). An introduction to sociolinguistics. Oxford: Basil Blackwell. 